\title{
GOLD, SODIUM, AND LIVER FUNCTION IN RHEUMATOID ARTHRITIS
}

\author{
BY \\ G. D. KERSLEY, L. MANDEL, and M. R. JEFFREY. \\ From the Rheumatism Research Unit, Royal National Hospital for Rheumatic Diseases, Bath
}

(RECEIVED FOR PUBLICATION OCTOBER 10, 1952)

In the Heberden Oration of 1950, Selye (1950) postulated that certain "conditioning factors", both exogenous and endogenous, may affect some of the responses of the General Adaptation Syndrome, or the target organs themselves. One of the factors cited was sodium which favoured the production of mineralo-corticoids, acting at the suprarenal level of the response. Previously, Selye (1946) had stated that diets rich in sodium tended to facilitate the production of the diseases of adaptation, whereas acidifying salts such as ammonium chloride tended to prevent these changes. He also suggested that many non-specific methods of treatment acted as forms of stress stimulating gluco-corticoid production.

In rheumatoid arthritis many "stresses", e.g. toxic drugs, hepatitis, or starvation, will produce amelioration of symptoms in a high proportion of cases. It was thought that gold, the "cure" that has stood the test of time, might act in this way, especially as the arthritis is almost invariably improved when toxic symptoms, such as dermatitis, occur. An experiment was therefore planned to see whether a reduction of salt in the diet and the use of "acidifying" salts would potentiate the beneficial effect of gold. At the same time liver function before and during treatment was also investigated, as it was thought that temporary depression of liver function might occur and might reduce the rapidity of inactivation of adrenal steroids.

\section{Method}

Calcium aurothiomalate (Aurocalcium) was given intramuscularly at weekly intervals. The first dose was one of $10 \mathrm{mg}$., then two doses of $25 \mathrm{mg}$., and thereafter $50 \mathrm{mg}$. until a total of approximately $1 \mathrm{~g}$. had been administered during the course of about 5 months. During this period, all patients took a low salt diet, calculated to contain less than $0.5 \mathrm{~g}$. daily. This entailed the avoidance of all salted foods and salt at the table, the cooking of food without added salt, the use of salt-free bread and margarine and a special salt-free synthetic milk. Patients were divided into three groups by random sampling and given enteric-coated tablets of sodium chloride (total amount $7 \cdot 5 \mathrm{~g}$. daily), or ammonium chloride (total amount $3.0 \mathrm{~g}$. daily), or lactose (inert control); all the tablets were similar in appearance.

All patients were suffering from active rheumatoid arthritis and were initially treated for a period of 4-6 weeks in hospital. Only those who agreed to co-operate fully and continue with the diet and injections for the full 5 months' course were started on treatment. On discharge from hospital, full arrangements were made for patients to continue the diet and injections at home. Close liaison and co-operation was maintained with all the general practitioners under whose care patients would remain. They were given full details of the trial and were requested to give the weekly gold injections.

Patients were assessed before, at monthly intervals during, and at the end of treatment, and also 3 months after the course was completed. On each occasion the weight, sedimentation rate, and haemoglobin levels were determined.

Several liver function tests were carried out in a proportion of cases before, during, and immediately after treatment. These included the zinc sulphate turbidity test (Kunkel, 1947), the galactose tolerance test (Bauer, 1906), the hippuric acid test (Pollak, 1947), and estimations of urinary urobilinogen and urobilin. In three patients, a liver biopsy was performed during the treatment.

\section{Results}

Clinical.-The clinical effects are summarized in Table I (overleaf), and the weights, sedimentation rates, and haemoglobin levels in Table II (overleaf). About half of the patients were much improved at the end of the course and that they maintained this improvement for the ensuing 3 months. The proportion of "much improved" cases was very similar in each group. Sedimentation rates and haemoglobin levels improved in all groups, again to much the same extent. All patients showed some loss of weight during treatment, but 3 months after the course ended the weight had begun to rise again. 
TABLE I

CLINICAL CHANGES NOTED IN THREE GROUPS OF PATIENTS

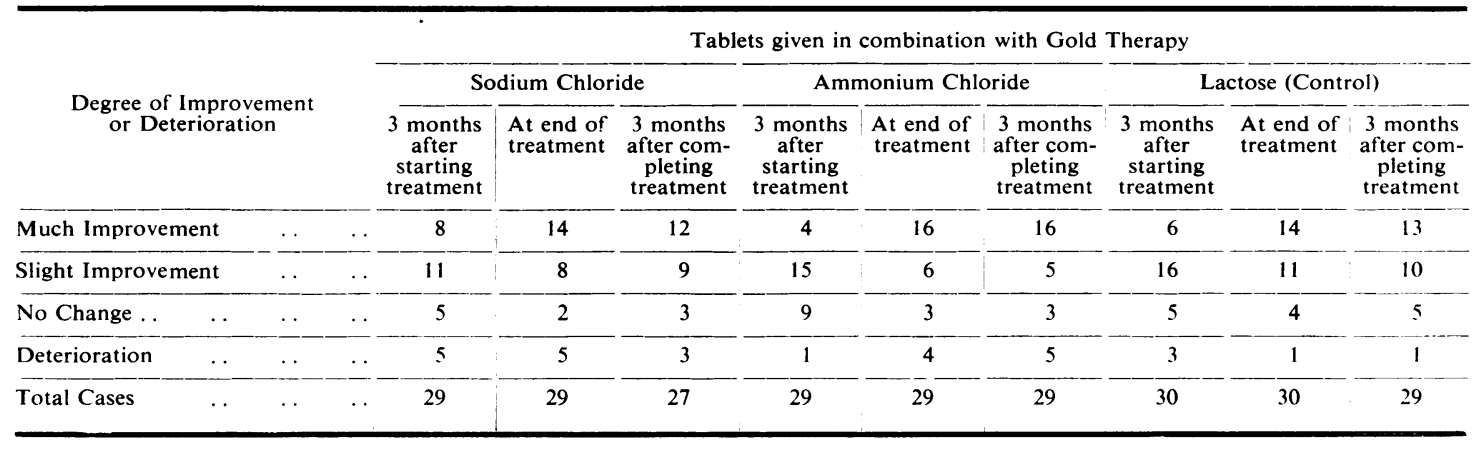

TABLE II

MEAN VALUES RECORDED IN WEIGHT, ERYTHROCYTE SEDIMENTATION RATE, AND HAEMOGLOBIN LEVEL IN THREE GROUPS OF PATIENTS

\begin{tabular}{|c|c|c|c|c|c|c|c|c|c|c|c|c|}
\hline \multirow{3}{*}{$\begin{array}{l}\text { Features } \\
\text { Assessed }\end{array}$} & \multicolumn{12}{|c|}{ Tablets given in combination with Gold Therapy } \\
\hline & \multicolumn{4}{|c|}{ Sodium Chloride } & \multicolumn{4}{|c|}{ Ammonium Chloride } & \multicolumn{4}{|c|}{ Lactose (Control) } \\
\hline & $\begin{array}{l}\text { Before } \\
\text { treat- } \\
\text { ment }\end{array}$ & $\begin{array}{l}3 \text { months } \\
\text { after } \\
\text { starting } \\
\text { treatment }\end{array}$ & $\begin{array}{l}\text { At end } \\
\text { of } \\
\text { treat- } \\
\text { ment }\end{array}$ & $\begin{array}{l}3 \text { months } \\
\text { after com- } \\
\text { pleting } \\
\text { treatment }\end{array}$ & $\begin{array}{c}\text { Before } \\
\text { treat- } \\
\text { ment }\end{array}$ & $\begin{array}{l}3 \text { months } \\
\text { after } \\
\text { starting } \\
\text { treatment }\end{array}$ & $\begin{array}{l}\text { At end } \\
\text { of } \\
\text { treat- } \\
\text { ment }\end{array}$ & $\begin{array}{l}3 \text { months } \\
\text { after com- } \\
\text { pleting } \\
\text { treatment }\end{array}$ & $\begin{array}{l}\text { Before } \\
\text { treat- } \\
\text { ment }\end{array}$ & $\begin{array}{l}3 \text { months } \\
\text { after } \\
\text { starting } \\
\text { treatment }\end{array}$ & $\begin{array}{c}\text { At end } \\
\text { of } \\
\text { treat- } \\
\text { ment }\end{array}$ & $\begin{array}{l}3 \text { months } \\
\text { after com- } \\
\text { pleting } \\
\text { treatment }\end{array}$ \\
\hline Weight (lb) & $121 \cdot 9$ & $117 \cdot 9$ & $116 \cdot 5$ & $118 \cdot 8$ & 120 & $114 \cdot 6$ & $115 \cdot 6$ & $118 \cdot 2$ & $131 \cdot 6$ & $126 \cdot 1$ & $125 \cdot 8$ & $128 \cdot 3$ \\
\hline $\begin{array}{l}\text { Erythrocyte sedi- } \\
\text { mentation rate } \\
\text { (mm./hr. Wester- } \\
\text { gren) } \quad \text {.. }\end{array}$ & 52 & 45 & 38 & 37 & 58 & 49 & 37 & 37 & 51 & 44 & 34 & 35 \\
\hline $\begin{array}{l}\text { Haemoglobin level } \\
(\text { g. } \%) \quad \ldots\end{array}$ & $11 \cdot 0$ & $11 \cdot 4$ & $11 \cdot 3$ & $12 \cdot 0$ & $11 \cdot 3$ & $11 \cdot 9$ & $11 \cdot 8$ & $12 \cdot 3$ & $11 \cdot 8$ & $12 \cdot 0$ & $12 \cdot 2$ & $12 \cdot 2$ \\
\hline Total Cases & 29 & 29 & 29 & 27 & 29 & 29 & 29 & 29 & 30 & 30 & 30 & 29 \\
\hline
\end{tabular}

Liver Function.-The zinc sulphate test gave raised values ( $>9.0$ units) initially in 21 out of 35 cases. These values tended to fall during treatment, but the degree of fall and the clinical change were not obviously related. The galactose tolerance test was normal at every estimation. Hippuric acid synthesis was initially low in five out of 21 women, less than 75 per cent. of an oral dose of $4 \mathrm{~g}$. sodium benzoate being excreted in $4 \mathrm{hrs}$. In these cases this function tended to improve during treatment, but without clear relation to clinical change. Several cases with a high initial excretion showed some decrease during treatment, though in none did the values become subnormal. Urinary urobilin and urobilinogen figures were never increased but frequently subnormal. The liver biopsies showed no significant abnormality.

Toxic Complications.-The only untoward effect of the gold was dermatitis. This occurred in eighteen patients out of 88 , there being no significant difference between the three groups of cases. In nine patients the course of gold had to be abandoned, but only one of these needed "BAL". In five cases the rash was slight and after an interval gold was given again in smaller doses without further trouble. Four patients developed a mild eruption shortly after completing the course. Of the eighteen patients who developed dermatitis, nine showed marked and five slight improvement in their arthritis.

\section{Conclusions}

It is clear that reduction of salt in the diet and addition of ammonium chloride did not enhance the effect of gold injections, either by clinical or by laboratory assessment. The low salt diet is very unappetizing after a short time and the loss of weight $c$ observed in all cases during therapy almost certainly resulted from reduced intake of a restricted and unpalatable diet.

Liver function, as judged by avowedly crude tests, showed no important abnormality, and in particular no deterioration during gold therapy. The high 
results of the zinc sulphate test were in keeping with the known increase in serum $\gamma$ globulin in rheumatoid disease.

The only toxic effect of gold was dermatitis which occurred in 20 per cent. of cases. The proportion of these cases showing clinical improvement did not differ from that in the series as a whole. No relation between dermatitis and liver function was observed.

\section{Summary}

(1) A low salt diet does not increase the effectiveness of gold therapy in rheumatoid arthritis.

(2) No evidence was found of impaired liver function during gold therapy.

(3) There was a marked clinical improvement associated with a drop in the sedimentation rate and an increase in the haemoglobin level in about 50 per cent. of all cases treated with gold.

We should like to acknowledge the help of Dr. R. Terry in connection with the liver biopsies, and the general practitioners of Bath, Bristol, and Wells for their co-operation in this investigation.

\section{REFERENCES}

Bauer, R. (1906). Wien. med. Wschr., 56,20

Kunkel, H. G. (1947). Proc. Soc. exp. Biol., N.Y., 66, 217.

Pollak, H. (1947). In "Recent Advances in Clinical Pathology," ed. S. C. Dyke, 1st ed., p. 151. Churchill, London.

Selye, H. (1946). J. clin. Endocr., 6, 117.

(1950). Brit. med. J., 1, 1383 .

Les sels d'or, le sodium, et la fonction hépatique dans l'arthrite rhumatismale

\section{RÉSUMÉ}

(1) Un régime pauvre en sel n'augmente pas l'efficacité de la chrysothérapie dans l'arthrite rhumatismale.

(2) On n'a pu démontrer aucune altération de la fonction hépatique au cours de la chrysothérapie.

(3) Dans $50 \%$ environ de tous les cas traités par des sels d'or, l'amélioration clinique était marquée, la vitesse de la sédimentation globulaire diminuée et le taux de l'hémoglobine augmenté.

El oro, el sodio, y la función hepática en la artritis reumatoide

\section{Sumario}

(1) Un régimen de restricción salina no aumenta la eficacia de la crisoterapia en la artritis reumatoide.

(2) $\mathrm{Ne}$ se pudo demostrar alteración de la función hepática durante la crisoterapia.

(3) En cerca de $50 \%$ de todos los casos tratados con sales de oro hubo una mejoría clínica marcada, la velocidad de la sedimentación globular disminuída y la tasa de la hemoglobina aumentada. 